\title{
HIV-1 Reverse Transcriptase: a potential target for marine products
}

\section{Leonardo A. Miceli, ${ }^{1}$ Alessandra M. T. de Souza, ${ }^{2}$ Carlos R. Rodrigues, ${ }^{3}$ Izabel C. N.P. Paixãoo, ${ }^{1}$ Valéria L. Teixeira, ${ }^{1}$ Helena C. Castro ${ }^{*, 1}$}

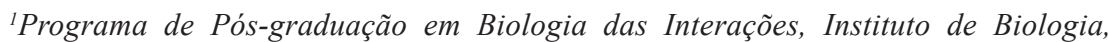
Universidade Federal Fluminense, Brazil,

${ }^{2}$ Laboratório de Modelagem Molecular e Pesquisa em Ciências Farmacêuticas, Instituto Macaé de Metrologia, Universidade Federal do Rio de Janeiro, Brazil, ${ }^{3}$ Laboratório de Modelagem Molecular e QSAR, Faculdade de Farmácia, Universidade Federal do Rio de Janeiro, Brazil.

\begin{abstract}
HIV-1 reverse transcriptase (HIV-1 RT) is a therapeutic target for the treatment of HIV-positive individuals or those already showing AIDS symptoms. In this perspective, the identification of new inhibitors for this enzyme is of great importance in view of the growing viral resistance to the existing treatments. This resistance has compromised the quality of life of those infected with multidrug-resistant strains, whose treatment options are already limited, putting at risk these individuals lives. The literature has recognized marine organisms and their products as natural sources for the identification of new therapeutic options for different pathologies. In this brief review, we consider the structure of HIV-1 RT and its most common inhibitors, as well as some marine diterpenes originally reported as HIV-1 RT inhibitors to encourage the identification and development of new marine antiviral prototypes.
\end{abstract}

Revista Brasileira de Farmacognosia Brazilian Journal of Pharmacognosy 22(4): 881-888, Jul./Aug. 2012

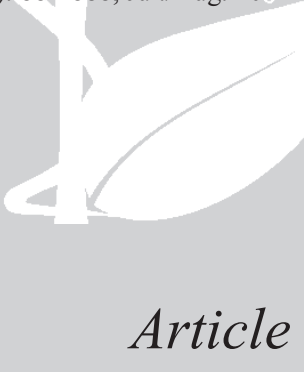

Received 12 Nov 2011

Accepted 22 Jan 2012

Available online 21 Jun 2012

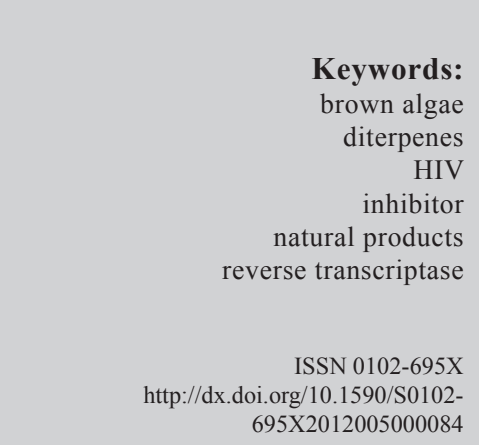

\section{Introduction}

Acquired immune deficiency syndrome (AIDS) is a pandemic disease officially recognized in 1981, which still continues to spread (Girard et al., 2011). So far, AIDS has killed more than 25 million people and. according to the annual survey of the World Health Organization (WHO) in 2010 , the number of infected people is stabilizing at around 33.5 million (WHO, 2010). Despite the discovery of antiviral treatment, the epidemic has reached 2.6 million people, of whom 370000 are children under fifteen years (WHO, 2010). This alarming statistic reflects a major problem in global health due not only to the financial aspect but also to the costs in human lives.

AIDS is caused by the Human Immunodeficiency Virus (HIV), a RNA-composed retrovirus of the Retroviridae family (Mulky \& Kappes, 2005) (Figure 1) (CDC, 2008; Balzarini, 2004). There are two types of virus, HIV-1 and HIV-2, HIV-2 being the least widespread (e.g., West African countries) with lower rates of mutation, virulence, transmissibility and pathogenicity than HIV-1 (Silva et al., 2008).

HIV infection is characterized by a deep suppression of the immune system of the infected individual due to a progressive depletion of immune cells in the host peripheral blood such as macrophages and, in particular, $\mathrm{T}$ lymphocytes. This process makes patients susceptible to opportunistic infections that become fatal due to this immunesuppression (Mosam et al., 2005; De Clercq, 2004).

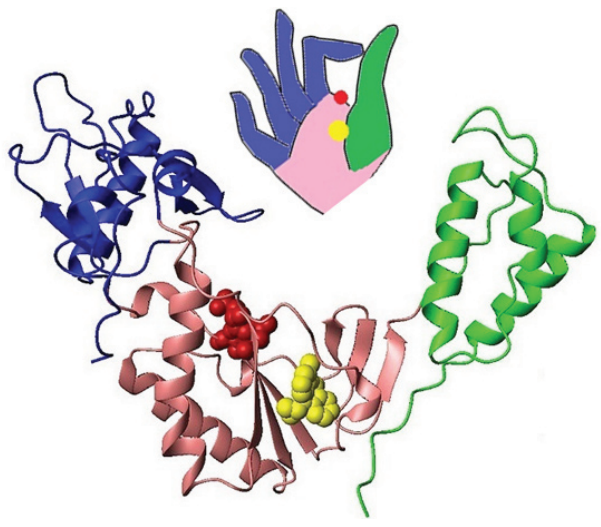

Figure 1. Three-dimensional structure of HIV-1 Reverse Transcriptase. The right-hand conformation representing the fingers subdomain (blue), palm (light red), thumb (green), the active site (red) and a reverse transcriptase inhibitor (yellow) in the binding site.

The Food and Drug Administration (FDA) approved 25 anti-HIV drugs that belong to seven different classes of drugs: nucleoside reverse transcriptase 
inhibitors (NRTI), nucleotide reverse transcriptase inhibitors (NtRTI), non-nucleoside reverse transcriptase inhibitors (NNRTI), protease inhibitors (PI), fusion inhibitors (FI), co-receptor inhibitors (CRI), and integrase inhibitors (INI) (Mehellou \& De Clercq, 2010).

HIV-1 has a replicative cycle that depends on different macromolecules, including viral receptors and enzymes (e.g., HIV-Reverse Transcriptase, HIV-Protease, HIV-Integrase). These enzymes are current targets for the antivirals clinically in use, whereas molecular recognition receptors on host CD4 cells (glycoprotein gp120, gp41 linked glycoprotein) are being explored for their potential (Debnath, 2005; Teixeira et al., 2011; Castro et al., 2011; Blanco et al., 2011; Pendri et al., 2011). HIV-1 Reverse Transcriptase (HIV-1 RT) - still an
effective therapeutical target

HIV-1 RT is a heterodimeric enzyme composed of two subunits of $66 \mathrm{kDa}$ and $51 \mathrm{kDa}$, (p66 and p51, respectively). The p66 subunit (560 amino acids) contains the polymerase and RNase-H active sites, both encoded by the same gene. The $\mathrm{p} 51$ subunit contains the first 440 amino acids of p66 and is derived from HIV-1 proteasemediated cleavage of the p66 subunit RNase $\mathrm{H}$ domain (Castro et al., 2006; Balzarini, 2004; Singh et al., 2010). The three-dimensional structure of the p66 subunit is compared with a right hand, containing four subdomains: fingers (residues 1-85 and 118-155), palm (86-117 and 156-236), thumb (237-318) and connection (319-426) (Kohlstaedt et al., 1992; Rodgers et al., 1995) (Figure 1).

HIV-1 Reverse Transcriptase catalyzes the synthesis of a double-stranded proviral DNA using the viral genomic RNA. The synthesis of the complementary strand DNA occurs by elongation of the primer tRNA, which is associated with the viral genome. The synthesis of the DNA first strand is initiated from the region of polypurine from the genomic RNA that is resistant to RNase-H and that remains on the new negative strand of DNA (-). All other reverse transcription steps include elongation of the primer DNA (Brautigam \& Steitz, 1998; Sarafianos et al., 2009).

HIV-1 RT has the ability to interact with substrates of different conformational structures (doublestranded DNA and single stranded RNA), but with low fidelity or processing capacity. Interestingly, this HIV-1 RT catalytic feature leads to the emergence of mutations at a frequency of about 104 per cycle (Arts \& Le Grice, 1998; Patel et al., 1995; Ehteshami \& Goette, 2008). Importantly, this high rate of mutation significantly conserves the biological activities of HIV-1 RT, while simultaneously conferring a multidrug-resistant profile to the virus (Das et al., 2004; Martinez-Picado \& Martínez, 2008).
The literature describes three main HIV-1 RT inhibitor types, divided by the mechanism of action including: inhibitors of HIV-1 RT polymeric activity; competitive inhibitors subdivided into the class of nucleosides (NRTI) and nucleotide (NtRTI) inhibitors; and non-competitive non-nucleoside inhibitors (NNRTI) (Caffrey 2011, Hatse et al., 1999; Menéndez-Arias, 2002).

Currently, in the most used treatment regimens including Highly Active Antiretroviral Therapy (HAART) (Menéndez-Árias et al., 2011), the use of at least one inhibitor of reverse transcriptase is highly recommended, including NRTI such as Zidovudine (AZT), lamivudine, didanosine, zalcitabine, stavudine, abacavir, emtricitabine and Adefovir, or NNRTIs such as delavirdine, Efavirenz and nevirapine (Table 1) (Pretorius et al., 2011). Monotherapy is avoided as well because treatment with only competitive inhibitors slowed the progression of AIDS, but the drug resistance arose quickly (Rao et al., 2004; Martin et al., 2010). Besides the viral resistance issue, these drugs cause different side effects (Table 1) that become extremely toxic in long term use (Temesgen et al., 2006; Sweeney \& Klumpp, 2008; Cihlar \& Ray, 2010).

\section{Seaweed natural products: a brief presentation of promising molecules}

According to Faulkner, the first reported use of marine organisms as a source of chemicals dates to 1600 $\mathrm{BC}$, when the Phoenicians used the secretion of shellfish to produce a dye for cloth (Faulkner, 1992).

Seaweeds are marine organisms that present a great diversity worldwide. In some countries in Asia and Africa where the population daily consumes Spirulina (=Arthrospira), a blue alga, a low incidence of infection with HIV-1 (AIDS) has been noticed (Ayehunie et al., 1998). These studies also showed that these algae have the property of stimulating the immune response (Teas et al., 2004).

Algae are primarily aquatic organisms that, despite their apparent simplicity present several complex biological systems, including defense, that are found in higher plants (Harper et al., 2001;Vidotti \& Rollemberg, 2004). These biological pathways involve different molecules that can be promising for treating certain pathologies, including HIV-infection (Alakurtti et al., 2006; Vo \& Kim, 2010; Kim \& Karadeniz, 2011).

The marine environment provides a rich source of chemical diversity for the screening and identification of new compounds with desirable antiviral properties. The use of marine natural products as anti-HIV agents has been described in the literature, promising molecules including the phlorotannins from brown algae (Phaeophyceae), sulfated polysaccharides from 
Chlorophyceae (green algae), Rhodophyceae (red algae) and Phaeophyceae (brown algae) and lectins such as Griffithsin from Griffithsia sp. (red algae) (Alakurtti et al., 2006; Vo \& Kim, 2010; Kim \& Karadeniz, 2011).

Terpenes as NNRTI models: looking at future anti-HIV treatment options?

NNRTI usually manifest side effects milder than those resulting from treatment with nucleosides since they are not analogues of natural compounds and involve no host cell biochemical machinery. Although the therapeutic potential of NNRTI has been compromised by the rapid development of resistance, they have been useful in combination therapy with nucleoside RT and protease inhibitors (Barreca et al, 2004). Thus, research exploring novel classes of safe and effective agents with low risk of cross-resistance with other antiretroviral drugs is currently in urgent need (WHO, 2011).

Many marine organisms are major producers of secondary metabolites derived from isoprene units, including the monoterpenes (C10), sesquiterpenes (C15), diterpenes (C20), triterpenes (C30) and tetraterpenes (C40). Among them, seaweeds are one of the main producers of these substances (Blunt et al., 2006). Of the 15,000 secondary metabolites of marine origin, approximately $55 \%$ are derived from terpenoids. This proportion can be much higher in some phyla, representing up to $90 \%$ of the metabolites isolated.

Table 1. Side effects of the most used NRTI (up) and NNRTI (below) of HIV-1 Reverse Transcriptase.

\begin{tabular}{|c|c|c|c|c|c|}
\hline Antiviral & Structure & $\begin{array}{l}\text { Collateral/ } \\
\text { side effects }\end{array}$ & Antiviral & Structure & $\begin{array}{l}\text { Collateral/ } \\
\text { side effects }\end{array}$ \\
\hline Zidovud ine (AZT) & $\mathrm{N}_{3}$ & $\begin{array}{l}\text { Myelosuppression with } \\
\text { neutropenia and anemia, } \\
\text { Nausea and vomiting. } \\
\text { Asthenia, malaise, } \\
\text { headache, insomnia, Skin } \\
\text { hyperpigmentation, nail and } \\
\text { mucous membranes. Rare: } \\
\text { lactic acidosis with hepatic } \\
\text { steatosis (fatal if severe). }\end{array}$ & $\begin{array}{l}\text { Stavudine } \\
\quad(\mathrm{d} 4 \mathrm{~T})\end{array}$ & & $\begin{array}{l}\text { Peripheral neuropathy, } \\
\text { pancreatitis, asymptomatic } \\
\text { acidemia, lipoatrophy. } \\
\text { Rare: lactic acidosis with } \\
\text { hepatic steatosis (fatal if } \\
\text { severe). }\end{array}$ \\
\hline Didanosine (ddI) & & $\begin{array}{l}\text { Gastrointestinal intolerance } \\
\text { (nausea and diarrhea), } \\
\text { peripheral neuropathy, } \\
\text { pancreatitis, asymptomatic } \\
\text { acidemia, lipoatrophy. Rare: } \\
\text { lactic acidosis with hepatic } \\
\text { steatosis (fatal if severe). }\end{array}$ & $\begin{array}{l}\text { Lamivudine } \\
\text { (3TC) }\end{array}$ & & $\begin{array}{l}\text { lactic acidosis with } \\
\text { hepatic steatosis }\end{array}$ \\
\hline Zalcitabine (ddC) & & $\begin{array}{c}\text { Peripheral neuropathy, } \\
\text { stomatitis, esophageal } \\
\text { ulcerations. Rare acidosis } \\
\text { lactate with hepatic steatosis } \\
\text { (fatal if severe). }\end{array}$ & $\begin{array}{l}\text { Abacavir } \\
(\mathrm{ABC})\end{array}$ & & $\begin{array}{c}\text { Reaction of } \\
\text { systemic respiratory } \\
\text { hypersensitivity and / or } \\
\text { gastrointestinal, usually } \\
\text { with fever and without } \\
\text { mucosal involvement. }\end{array}$ \\
\hline Nevirapine & & $\begin{array}{c}\text { Rash, Stevens-Johnson } \\
\text { Syndrome, Elevated } \\
\text { transaminases blood } \\
\text { level, hepatitis, severe } \\
\text { hypersensitivity reaction. }\end{array}$ & Delavirdine & & $\begin{array}{c}\text { Rash, headache, elevation } \\
\text { of transaminases }\end{array}$ \\
\hline Efavirenz & $\mathrm{H}$ & $\begin{array}{c}\text { Rash, Stevens-Johnson } \\
\text { Syndrome. Neuropsychiatric } \\
\text { symptoms: sleep disturbances } \\
\text { (restless sleep, insomnia, } \\
\text { drowsiness, nightmares, } \\
\text { bizarre dreams), dizziness, } \\
\text { vertigo, irritability, agitation, } \\
\text { depression, euphoria, difficulty } \\
\text { concentrating, amnesia, } \\
\text { hallucinations. Elevation of } \\
\text { transaminases. Dyslipidemia. }\end{array}$ & Etravirine & & $\begin{array}{l}\text { Rash, Stevens-Johnson } \\
\text { syndrome, toxic epidermal } \\
\text { necrosis and multiform } \\
\text { erythema, as well as } \\
\text { hypersensitivity reactions, } \\
\text { hepatic failure }\end{array}$ \\
\hline
\end{tabular}


Marine algae are among the main producers of diterpenes showing antibacterial, antiviral, antifungal, and other biological activities (Harper et al., 2001). The literature describes diterpenes isolated from the Dictyota alga species with potential antiviral activity (DePaula et al., 2011). The main diterpene compounds isolated from Dictyota menstrualis (Hoyt) Schnetter, Hörning \& WeberPeukert, identified as 6-hydroxydichotoma-3,14-dien-1,17dial (1) and its acetate derivative 6-acetoxydichotoma3,14-dieno-1,17-dial (2) (Figure 2), exhibit inhibitory activities against HIV-1 replication affecting HIV-1 reverse transcriptase (RT) activity in a dose-dependent form (Pereira et al. 2004, 2005). A similar antiviral profile was observed in a dollabelane diterpene isolated from Dictyota pfaffii Schnetter (3-5) (Figure 2). Apparently these marine products act as NNRTI.
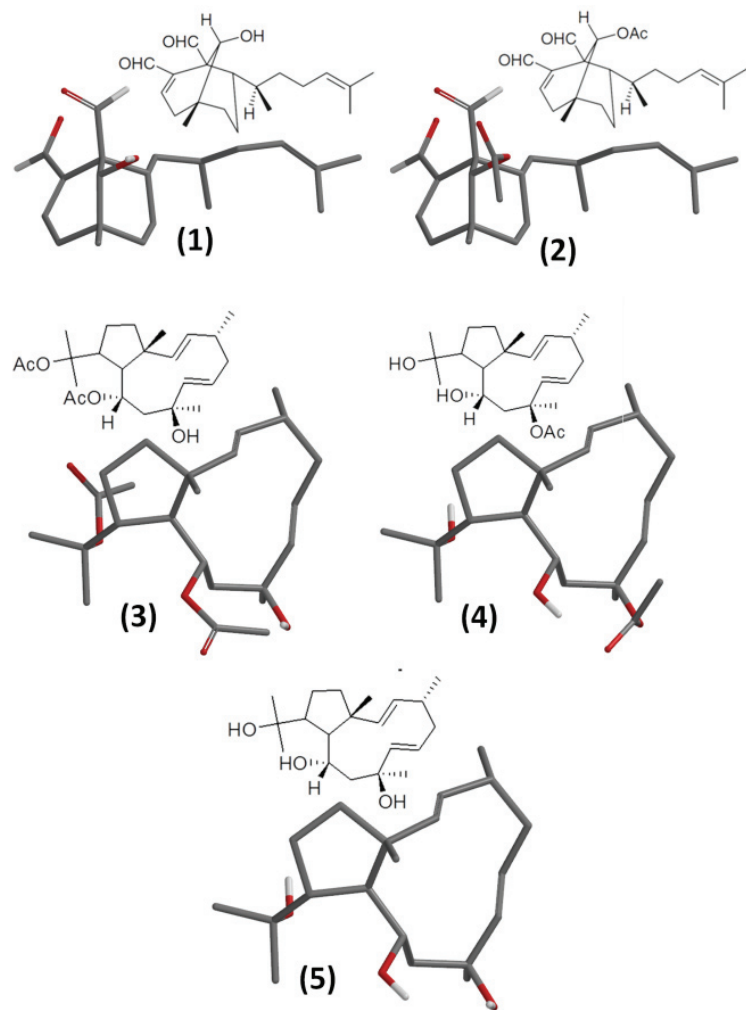

Figure 2. Antiviral diterpenes isolated from the brown algae $D$. menstrualis (1-2) and D. pfaffii (3-5).

The NNRTI were first described when TIBO and nevirapine derivatives were discovered during research on HIV-1 RT inhibition (Pauwels et al., 1990, Shih et al., 1991). NNRTI are chemically diverse, with one class being considerably different from another in terms of chemical composition and size. This is analogous to the complexity of marine natural products, with a great variety of structures with different degrees of biological activity (De Clercq, 1998). NNRTI have in common the affinity for the extremely flexible hydrophobic p66 chain located near the active site (approximately $10 \AA$ away) and located between the $\beta$-sheet-6-9- $\beta-\beta$ and $\beta-10-12-13-\beta-\beta-14$ from the palm domain, called the "non-nucleoside inhibitor binding pocket" (NNIBP) (Boyer et al., 1994a, 1994b; Sluis-Cremer et al., 2004; Martin et al., 2010; Zhan et al., 2011). The inhibition mechanism is due to the expansion of the region of NNBIP, since this hydrophobic "pocket" is closed during the active period of TR. The opening of this region involves a large displacement of the aromatic side chains of Tyr181, Tyr188 and Trp229 and a rotation of the leaves $\beta-\beta-12-13-\beta-14$, resulting in a breakdown of the primer grip in the direction that the complex primertemplate moves during the subsequent incorporation of nucleotides (Das et al., 2004) (Figure 3).

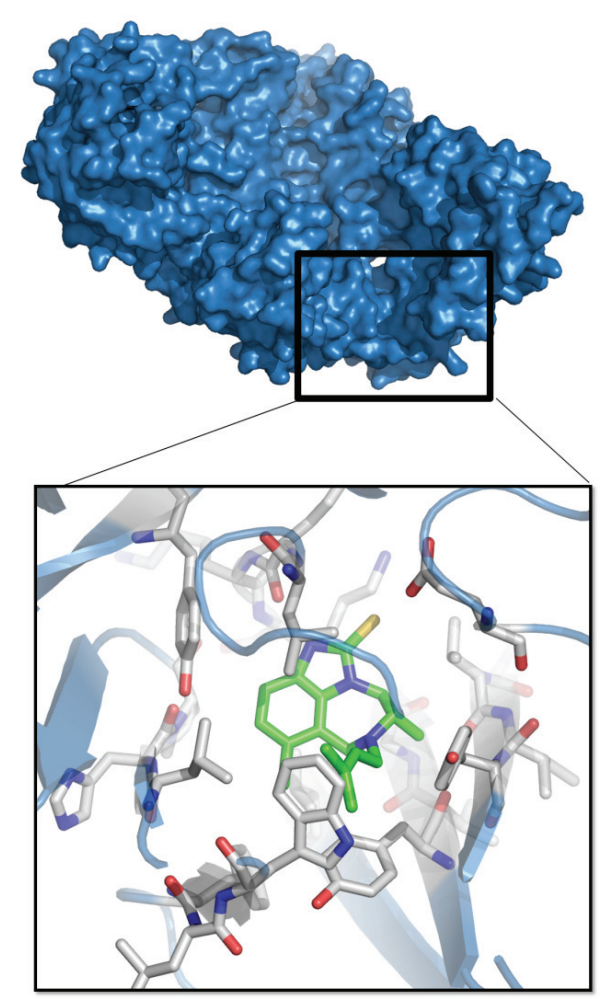

Figure 3. Three-dimensional structure of the NNRTI binding site. In green, the inhibitor TIBO.

Our group showed that the diterpene 8,10,18trihydroxy-2,6-dolabelladiene (THD, 5), obtained from the extract of Dictyota pfaffi or by reducing 10,18-diacetoxy8-hydroxy-2,6-dolabelladiene (3), showed significant antiviral activity, up to 3 times higher with this chemical modification (Barbosa et al., 2003; Barbosa et al., 2004; Cirne-Santos et al., 2006). Our experimental study confirmed a dose-dependent anti-HIV-1 TR activity, with an IC50 of $16.5 \mu \mathrm{M}$, inhibition levels ranging from $27 \%$ $(3 \mu \mathrm{M})$ to $95 \%(100 \mu \mathrm{M})$, and $85 \%$ viability of peripheral blood mononuclear cells (PBMC) at concentrations of 200 $\mu \mathrm{M}$ (Barbosa et al. 2003; Cirne-Santos et al., 2006).

Importantly, dolabelladienetriol blocked 
the synthesis and integration of HIV-1 provirus and completely abrogated viral replication in primary cells. Studies of the kinetic mode of action revealed that dolabelladienetriol is a nonnucleoside RT inhibitor (NNRTI), acting as a noncompetitive inhibitor, with a Ki value equal to $7.2 \mu \mathrm{M}$.

Interestingly, dolabelladienetriol provided an additive effect with the nucleoside RT inhibitor AZT, and a synergistic effect with the protease inhibitor atazanavir sulphate. There was no increment of the antiHIV-1 effect resulting from the combination between dolabelladienetriol and the NNRTI nevirapine. Using a large panel of HIV-1 isolates harboring NNRTI resistance mutations, we found no cross-resistance between dolabelladienetriol and clinically available NNRTIs (Cirne-Santos et al., 2008).

Our group also described two other diterpene skeleton dichotomanes with anti-HIV-1 RT antiviral action, (6R)-6-hydroxydichotoma-3,14-diene-1,17dial (HDD, 1) and its acetate derivative (6R)-6acetoxydichotoma-3,14-diene-1,17-dial (DDA, 2) extracted from the brown algae Dictyota menstrualis (Pereira et al., 2004; Pereira et al., 2005). While HDD showed a value of inhibition of HIV-RT of IC50 $10 \mu \mathrm{M}$, the value for DDA was $35 \mu \mathrm{M}$ (Pereira et al., 2004; Pereira et al., 2005). None of these diterpenes affected the DNA-dependent DNA-polymerase (DDDP) activity of HIV-1 RT. The RNA-DDP activities of AMV-RT and MMLV-RT enzymes were also inhibited by HDD and DDA. In contrast to the HIV-1 enzyme, the DDDP activities of AMV-RT and MMLV-RT enzymes were significantly reduced. Taken together, our results demonstrate that HDD is a more effective inhibitor of the viral reverse transcriptases from HIV-1, AMV and MMLV than DDA.

The kinetic analyses of the HIV-1 RT demonstrate that both diterpenes have similar mechanisms of inhibition of RDDP activity (Pereira et al., 2005). The mechanism of inhibition of HIVRT by terpenes was evaluated and apparently occurs by forming a "butterfly-like" structure, as observed for NNRTIs inhibitors (Castro et al., 2006, De Clercq, 2004).

More recently, four diterpenes from other Dictyotaceae, Canistrocarpus cervicornis (Kützing), three dolastanes and a secodolastane diterpene were also described with anti HSV-1 (Vallim et al. 2010) and anti-HIV-1-RT profiles including $(4 R, 9 R, 14 S)-4,9,14-$ trihydroxy-dolast-1(15),7-diene (6), the isolinearol (7), (4R,7R,14S)-4,7,14-trihydroxydolast-1(15),8-diene (8) and $(4 R, 7 R, 14 S)-4 \alpha$,7-diacetoxy-14-hydroxydolast1(15),8-diene (9). Although these natural products were known since the 80 's from Dictyota cervicornis (Teixeira et al, 1986a, 1986b; Kelecom \& Teixeira 1988), the antiviral activity was only identified in 2010 . The results of anti-HIV-1 RT led to the registration of a patent application in 2010 (Paixão et al., 2010).<smiles>C=C1CC[C@@H](O)[C@]2(C)CC=C3[C@](C)(O)CC[C@]3(C)C[C@]12O</smiles><smiles>C=C1CC[C@@H](O)[C@]2(C)CC[C@](O)(CCC(C)=O)[C@]1(C)C2</smiles><smiles>C=C1CC[C@@H](O)[C@]2(C)C[C@H](O)C3=C(C(C)C)CC[C@]3(C)C[C@]12O</smiles><smiles>C=C1CC[C@H](OC(C)=O)[C@@]2(C)CC(O)=C3[C@@H](C(C)C)CC[C@]3(C)C[C@]12O</smiles>

8

9

\section{Conclusion}

Far from pointing out terpenes as the only marine products able to inhibit HIV-RT, this brief review reinforces the biotechnological potential and the need to explore marine resources as thoroughly as reasonably possible in order to find new treatments not only for HIV, but also for other infectious diseases such as herpes.

\section{Acknowledgment}

The authors thank CNPq-Universal, CAPES, FOPESQ-UFF and FAPERJ for financial support and fellowships.

\section{References}

Alakurtti S, Makela T, Koskimies S, Yli-Kauhaluoma J 2006. Pharmacological properties of the ubiquitous natural product betulin. Eur J Pharm Sci 29: 1-13.

Arts EJ, Le Grice SF 1995. Interaction of retroviral reverse transcriptase with template-primer duplexes during replication. Progr Nucleic Acid Res Mol Biol 58: 339393.

Ayehunie S, Belay A, Baba TW, Ruprecht RM 1998. Inhibition of HIV-1 replication by an aqueous extract of Spirulina platensis (Arthrospira platensis). J Acq Imm Deficl 18: 7-12.

Balzarini J 2004. Current status of the non-nucleoside reverse transcriptase inhibitors of human immunodeficiency virus type 1. Curr Top Med Chem 4: 921-944.

Barbosa JP, Pereira RC, Abrantes JL, Cirne-Santos CC, Rebello MA, Frugulhetti ICPP, Teixeira VL 2004. In vitro antiviral diterpenes from the Brazilian brown alga Dictyota pfaffii. Planta Med 70: 856-860.

Barbosa JP, Teixeira VL, Villa R, Pereira RC, Abrantes JL, Frugulhetti ICPP 2003. A dolabellane diterpene from 
the Brazilian brown alga Dictyota pfaffii. Biochem Syst Ecol 3: 1451-1453.

Barreca ML, Rao A, De Luca L, Zappalà M, Gurnari C, Monforte P, De Clercq E, Van Maele B, Debyser Z, Witvrouw M, Briggs JM, Chimirri A 2004. Efficient 3D database screening for novel HIV-1 IN inhibitors. $J$ Chem Inf Model 44: 1450-1455.

Blanco J-L, Varghese V, Rhee S-Y, Gatell JM, Shafer RW 2011. HIV-1 Integrase Inhibitor Resistance and Its Clinical Implications. J Infect Dis 31: 1204-14.

Blunt J, Copp B, Munro M, Northcote P, Prinsep M 2006. Marine natural products RID D-3706-2009. Nat Prod Rep 23: 26-78.

Boyer PL, Ferris AL, Clark P, Whitmer J, Frank P, Tantillo C, Arnold E, Hughes SH 1994. mutational analysis of the fingers and palm subdomains of Human Immunodeficiency Virus Type-1 (HIV-1) reverse transcriptase. J Mol. Biol 243: 472-483.

Boyer PL, Tantillo C, Jacobo-Molina A, Nanni RG, Ding J, Arnold E, Hughes SH 1994. Sensitivity of wild-type human immunodeficiency virus type 1 reverse transcriptase to dideoxynucleotides depends on template length; the sensitivity of drug-resistant mutants does not. PNAS 91: 4882-4886.

Brautigam CA, Steitz TA 1998. Structural and functional insights provided by crystal structures of DNA polymerases and their substrate complexes. Curr Opin Struct Biol 8: 54-63.

Caffrey M 2011. HIV envelope: challenges and opportunities for development of entry inhibitors. Trends Microbiol 19: 191-197.

Castro HC, Abreu PA, Geraldo RB, Martins RCA, dos Santos R, Loureiro NIV, Cabral LM, Rodrigues CR 2011. Looking at the proteases from a simple perspective. $J$ Mol Recognit 24: 165-81.

Castro HC, Loureiro NIV, Pujol-Luz M, Souza AMT, Albuquerque MG, Santos DO, Cabral LM, Frugulhetti ICPP, Rodrigues CR 2006. HIV-1 reverse transcriptase: a therapeutical target in the spotlight. Curr Med Chem 13: 313-324.

CDC Centers for Disease Control and Prevention. 2008. Global HIV /AIDS. http://www.cdc.gov/hiv/resources/ qa/index.htm, accessed Nov 2011.

Cihlar T, Ray AS 2010. Nucleoside and nucleotide HIV reverse transcriptase inhibitors: 25 years after zidovudine. Antivir Res 85: 39-58.

Cirne-Santos CC, Teixeira VL, Castello-Branco LR, Frugulhetti ICPP, Bou-Habib DC 2006. Inhibition of HIV-1 replication in human primary cells by a dolabellane diterpene isolated from the Brazilian algae Dictyota pfaffii. Planta Med 72: 295-299.

Cirne-Santos TM, Teixeira, VL, Fontes, CF, Rebello MA, Castello-Branco LR, Abreu CM.,Tanuri A, Frugulhetti ICPP, Bou-Habib DC 2008. The dolabellane diterpene dolabelladienetriol is a typical noncompetitive inhibitor of HIV-1 reverse transcriptae enzyme. Antivir Res 77: 64-71.

Das K, Clark, Lewi PJ, Heeres J, de Jonge MR, Koymans LMH, Vinkers HM, Daeyaert F, Ludovici DW, Kukla MJ, De Corte B, Kavash RW, Ho CY, Ye H, Lichtenstein MA, Andries K, Pauwels R, De Béthune MP, Boyer PL, Clark P, Hughes SH, Janssen PA, Arnold E 2004. Roles of conformational and positional adaptability in structurebased design of TMC125-R165335 (etravirine) and related non-nucleoside reverse transcriptase inhibitors that are highly potent and effective against wild-type and drug-resistant HIV-1 variants. J Med Chem 47: 2550-2260.

De Clercq E 1998. The role of non-nucleoside reverse transcriptase inhibitors (NNRTIs) in the therapy of HIV-1 infection. Antivir Res 38: 153-179.

De Clercq E 2004. Anti-HIV chemotherapy: Current state of the art. Med Chem Res 13: 439-478.

De Paula JC, Vallim MA, Teixeira VL 2011. What are and where are the bioactive terpenoids metabolites from Dictyotaceae (Phaeophyceae)? Rev Bras Farmacogn 21: 216-28.

Debnath AK 2005. Application of 3D-QSAR techniques in antiHIV-1 drug design - an overview. Curr Pharm Design 11: 3091-3110.

Ehteshami M, Goette M 2008. Effects of Mutations in the connection and RNase H domains of HIV-1 reverse transcriptase on drug susceptibility. Aids Rev 10: 224235.

Faulkner DJ 1992. Marine natural products. Nat Prod Rep 9: 323-364

Girard MP, Osmanov S, Assossou OM, Kieny MP 2011. Human immunodeficiency virus (HIV) immunopathogenesis and vaccine development: A review. Vaccine 29: 61916218.

Harper MK, Bugni TS, Copp BR. James RD, Lindsay BS, Richardson AD, Schnabel PC, Tasdemir D, Vanwagoner RM, Verbitski SM, Ireland CM 2001. Introduction to the chemical ecology of marine natural products. In: Mcclintock JB, Baker BJ (Eds.). Marine Chemistry Ecology. Boca Raton: C.R.C. Press, p. 3-69.

Kelecom A, Teixeira VL 1988. Dolastane diterpenes from the marine brown alga Dictyota cervicornis. Phytochemistry 27: 2907-2909.

Kim SK, Karadeniz F 2011. Anti-HIV Activity of extracts and compounds from marine algae. Adv Food Res 64: 255265.

Kohlstaedt LA, Wang J, Friedman JM, Rice PA, Steitz TA 1992. Crystal structure at $3.5 \AA$ resolution of HIV-1 reverse transcriptase complexes with an inhibitor. Science 256: 1783-1790.

Martin JC, Hitchcock MJM, De Clercq E, Prusoff WH 2010. Early nucleoside reverse transcriptase inhibitors for the treatment of HIV: A brief history of stavudine (D4T) and its comparison with other dideoxynucleosides. 
Antivir Res 85: 34-38.

Martinez-Picado J, Martínez MA 2008. HIV-1 reverse transcriptase inhibitor resistance mutations and fitness: A view from the clinic and ex vivo. Virus Res 134: 10423.

Menéndez-Arias L 2002. Targeting HIV: antiretroviral therapy and development of drug resistance. Trends in Pharmacol Sci 23: 381-388.

Menéndez-Arias L, Betancor G, Matamoros T 2011. HIV-1 reverse transcriptase connection subdomain mutations involved in resistance to approved non-nucleoside inhibitors. Antivir Res 92: 139-149.

Mechellou, Y, De Clercq E 2010. Twenty-six years of antiHIV-1 drug discovery: where do we stand and where do we go? J Med Chem 53: 521-538

Mosam A, Cassol E, Page T, Bodasing U, Cassol S, Dawood H, Friedland GH, Scadden DT, Aboobaker J, Jordaan JP, Lalloo UG, Esterhuizen TM, Coovadia HM 2005. Generic antiretroviral efficacy in AIDS-associated Kaposi's sarcoma in sub-Saharan Africa. Aids 19: 441443.

Mulky A, Kappes JC 2005. Analysis of human immunodeficiency Virus Type 1 Reverse Transcriptase subunit structure/ function in the context of infectious virions and human target cells. Antimicrob Agents Chemother 49: 37623769.

Paixão INPP, Teixeira VL, Cirne-Santos CC, Vallim MA, Cavalcanti DN, Castello-Branco LR, De-Paula JC 2010. Extrato, composição farmacêutica e processo de obtenção de substâncias que apresentam ação inibitória contra o vírus HIV-1. INPI register number 221007209660 in 10/22/2010.

Patel PH, Jacobo-Molina A, Ding J, Tantillo C, Clark AD Jr, Raag R, Nanni RG, Hughes SH, Arnold E 1995. Insights into DNA polymerization mechanisms from structure and function-analysis of HIV-1 reverse-transcriptase. Biochem 34: 5351-5363.

Pauwels R, Andries K, Desmyter J, Schols D, Kukla MJ, Breslin HJ, Raeymaeckers A, Van Gelder J, Woestenborghs R, Heykants J, Schellekens K, Janssen MAC, De Clercq E, Janssen PAJ 1990. Potent and selective inhibition of HIV-1 replication in vitro by a novel series of TIBO derivatives. Nature 343: 470-474.

Pendri A, Meanwell NA, Peese KM, Walker MA 2011. New first and second generation inhibitors of human immunodeficiency virus-1 integrase. Exp Op Therap Patents 21: 1173-1189.

Pereira HS, Leão-Ferreira LR, Moussatché N, Teixeira VL, Cavalcanti DN, Costa LJ, Diaz R, Frugulhetti ICPP 2004. Antiviral activity of diterpenes isolated from the Brazilian marine alga Dictyota menstrualis against human immunodeficiency virus type 1 (HIV-1). Antivir Res 64: 69-76.

Pereira HS, Leão-Ferreira LR, Moussatché N, Teixeira VL, Cavalcanti DN, Costa LJ, Diaz R, Frugulhetti ICPP
2005. Effects of diterpenes isolated from the Brazilian marine alga Dictyota menstrualis on HIV-1 reverse transcriptase. Planta Med 71: 1019-1024.

Pretorius E, Klinker H, Rosenkranz B 2011. The role of therapeutic drug monitoring in the management of patients with Human Immunodeficiency Virus Infection. Ther Drug Monit 33: 265-274.

Rao A, Balzarini J, Carbone A, Chimirri A, De Clercq E, Monforte $\mathrm{M}$, Monforte $\mathrm{P}$, Pannecouque $\mathrm{C}$, Zappalà M 2004. Synthesis of new 2,3-diaryl-1,3-thizolidin-4-ones as anti-HIV-1 agents. Il Farmaco 59: 33-39.

Rodgers DW, Gamblin SJ, Harris BA, Ray S, Culp JS, Hellmig B, Woolf DJ, Debouck C, Harrison SC 1995. The structure of unliganded reverse transcriptase from the human immunodeficiency virus type 1. PNAS 92: 12221226.

Sarafianos SG, Marchand B, Das K, Himmel DM, Parniak MA, Hughes SH, Arnold E 2009. Structure and function of HIV-1 reverse transcriptase: molecular mechanisms of polymerization and inhibition. $J$ Mol Biol 385: 693713.

Shih CK, Rose JM, Hansen GL, Wu JC, Bacolla A, Griffin JA 1991. Chimeric human immunodeficiency virus type 1/ type 2 reverse transcriptases display reversed sensitivity to nonnucleoside analog inhibitors. PNAS 88: 98789882.

Silva TI, Cotton M, Rowland-Jones SL 2008. HIV-2: the forgotten AIDS virus. Trends Microbiol 16: 588-595.

Singh K, Marchand B, Kirby KA, Michailidis E, Sarafianos SG 2010. Structural aspects of drug resistance and inhibition of HIV-1 Reverse Transcriptase Viruses 2: 606-638.

Sluis-Cremer N, Temiz NA, Bahar I 2004. Conformational changes in HIV-1 reverse transcriptase induced by nonnucleoside reverse transcriptase inhibitor binding. Curr HIV Res 2: 323-332.

Sweeney ZK, Klumpp K 2008. Improving non-nucleoside reverse transcriptase inhibitors for first-line treatment of HIV infection: The development pipeline and recent clinical data. Curr Opin Drug Disc 11: 458-470.

Teas J, Hebert JR, Fitton JH, Zimba PV 2004. Algae - A poor man's HAART? Med Hypotheses 62: 507-510.

Teixeira C, Gomes JRB, Gomes P, Maurel F 2011. Viral surface glycoproteins, gp120 and gp41, as potential drug targets against HIV-1: Brief overview one quarter of a century past the approval of zidovudine, the first anti-retroviral drug. Eur J Med Chem 6: 979-992.

Teixeira VL, Tomassini T, Fleury BG, Kelecom A 1986a. Dolastane and secodolastane diterpenes from the brown alga, Dictyota cervicornis. J Nat Prod 49: 570-575.

Teixeira VL, Tomassini T, Kelecom A 1986b. Cervicol, a further secodolastane diterpene from the marine brown alga Dictyota cervicornis Kützing (Phaeophyceae, Dictyotaceae). Bull Soc Chim Belg 95: 263-268.

Temesgen Z, Warnke D, Kasten MJ 2006. Current status of antiretroviral therapy. Expert Opin Pharmaco 7: 1541- 
1554.

Vallim, MA, Barbosa JE, Cavalcanti DN, De-Paula JC, Silva VAGG, Teixeira VL, Paixão ICNP 2010. In vitro antiviral activity of diterpenes isolated from the Brazilian brown alga Canistrocarpus cervicornis. J Med Plants Res 4: 2379-2382.

Vidotti EC, Rollemberg MDCE 2004. Algae: From aquatic environment economy to bioremediation and analytical chemistry. Quim Nova 27: 139-145.

Vo TS, Kim SK 2010. Potential Anti-HIV Agents from marine resources: an overview. Mar Drugs 8: 2871-2892.

WHO 2010. HIV/AIDS - Data and statistics. Global summary of the AIDS epidemic. http://www.who.int/hiv/data/en, accessed Nov 2011.
Zhan P, Chen X, Li D, Fang Z, De Clercq E, Liu X 2011. HIV-1 NNRTIs: Structural diversity, pharmacophore similarity, and implications for drug design. Med Res Rev doi: 10.1002/med.2022, 2011.

\section{*Correspondence}

\section{Helena Carla Castro}

LABiEMol, Departamento de Biologia Celular e Molecular, Instituto de Biologia, Universidade Federal Fluminense 24210-130 Niterói-RJ, Brazil

hcastrorangel@vm.uff.br

Tel. +55212629 9954

Fax: +552126292376 